\title{
PENGARUH DINAMIKA KELOMPOK SOSIAL TERHADAP ANGKA KEJADIAN DAN PENYEMBUHAN PENYAKIT TUBERKULOSIS PARU DI WILAYAH PUSKESMAS MOJOROTO
}

\author{
(The effect of social group dynamics of events and healing tuberculosis lung disease in \\ Public Health Center Mojoroto) \\ Pardjono, Puguh Santoso, Dyah Ika Krisnawati, Erna Susilowati, Elfi Quyumi, \\ Novita Setyowti
}

\begin{abstract}
Pulmonary tuberculosis is a chronic disease that must be controlled through a comprehensive program to achieve Indonesian Health Program in 2012. From retrospective data recorded and reported, tuberculosis (Pulmonary Tuberculosis) is one of the cases that should get routine examination and scheduled to visit health center. Public Health Center activities to the TB's patient are by promotive, preventive, rehabilitative, and curatif coordinate with activities in the development of health centers

The purpose of this study was to determine the effect of social group dynamics of events and healing tuberculosis lung disease in Public Health Center Mojoroto. The population in this study is all patients who was came in Public Health Center Mojoroto totaled 50 people. The sampling technique used is total sampling so the number of samples taken as many as 50 people..

Analysis for the effect of social group dynamics of events and healing tuberculosis lung disease is McNemar-Bowker Test. From the processing of the analysis statistic obtained probability value is more than 0.05, which means there is no effect of social group dynamics of events and healing tuberculosis lung disease in Public Health Center Mojoroto.

The results showed no significant effect of group dynamics activity on the incidence of tuberculosis and cure of pulmonary tuberculosis. Most of sputum examination results before and after shown the negative result may caused by patients can not cough up sputum well.
\end{abstract}

Keywords: tuberculosis lung disease, social group dynamics

\section{PENDAHULUAN}

Tuberkulosis merupakan salah satu masalah kesehatan masyarakat yang penting di tingkat global, regional, nasional, maupun lokal. Tuberkulosis menyebabkan 5000 kematian per hari, atau hampir 2 juta kematian per tahun di seluruh dunia. TB, HIV/AIDS, dan malaria secara bersama-sama merupakan penyebab 6 juta kematian setiap tahun. Seperempat juta (25\%) kematian karena TB berhubungan dengan HIV. Insidensi global TB terus meningkat sekitar $1 \%$ per tahun, terutama karena peningkatan pesat insidensi TB di Afrika berkaitan dengan komorbiditas HIV/AIDS (WHO, 2009).
Tuberkulosis paru merupakan penyakit kronis yang harus dikontrol melalui program komprehensif untuk mencapai Indonesia sehat tahun 2012. Namun sampai tahun 2010 belum tercapai tujuan tersebut. Data yang dilaporkan WHO Indonesia menempati urutan nomor tiga setelah India dan Cina yaitu dengan angka 1,7 juta orang Indonesia. Secara teori apabila tidak diobati, tiap satu orang penderita tuberkulosis akan menularkan pada sekitar 10 sampai 15 orang dan cara penularannya dipengaruhi berbagai faktor.

Data dari Depertemen Kesehatan menyebutkan bahwa Tuberkulosis paru merupakan penyakit yang perlu mendapat 
perhatian karena walaupun prevalensinya dapat diturunkan dari sekitar 2,9 per 1000 penduduk menjadi sekitar 2,4 per 1000 penduduk pada akhir pelita VI, dan di Jawa, Bali dan Aceh prevalensinya masih berkisar antara 6,5 sampai 6,9 per 1000 penduduk. (Depkes RI, 2005). Secara Regional prevalensi TB BTA positif di Indonesia dikelompokkan dalam 3 wilayah, yaitu: 1) wilayah Sumatera angka prevalensi TB adalah 160 per 100.000 penduduk; 2) wilayah Jawa dan Bali angka prevalensi TB adalah 110 per 100.000 penduduk; 3) wilayah Indonesia Timur angka prevalensi TB adalah 210 per 100.000 penduduk. Khusus untuk propinsi DIY dan Bali angka prevalensi TB adalah 68 per 100.000 penduduk. Mengacu pada hasil survey prevalensi tahun 2004, diperkirakan penurunan insiden TB BTA positif secara Nasional 3$4 \%$ setiap tahunnya.

Dari berbagai kasus penyakit yang ditangani oleh Puskesmas, data secara restropektif pada buku pencatatan dan pelaporan, penyakit TBC (Tuberkulosis Paru) merupakan salah satu kasus yang harus menjalani pemerikasaan rutin dan terjadual di Puskesmas. Kegiatan Puskesmas dalam menangani kasus TBC ini dengan cara promotif, preventif, curatif dan rehabilitatif sesuai dengan pengembangan kegiatan yang ada di Puskesmas.

Dari hasil studi pendahuluan yang telah dilakukan di Dinas kesehatan kota Kediri, didapatkan penderita TBC terbanyak di wilayah kerja puskesmas Sukorame, Campurejo, dan Balowerti. Pada wilayah Puskesmas Sukorame dengan jumlah penduduk 46.076 jiwa pada bulan Januari sampai Juni diperkirakan 493 jiwa suspek TBC.

Banyak cara untuk menurunkan peningkatan angka penderita TBC diantaranya dengan berprilaku sehat. Berdasar wawancara dengan beberapa warga Puskesmas Sukorame semua belum mengerti secara mendetail cara pencegahan penularan TBC. Masalah ini merupakan tugas tenaga kesehatan dalam upaya promotif dan preventif

Berdasarkan gambaran diatas maka perlu dibina dan dilakukan pendampingan dengan memberikan pengetahuan dan praktik tentang tata cara mencegah penularan penyakit TBC baik dalam keluarga maupun di masyarakat berupa penyuluhan tentang perilaku sehat baik untuk penderita TBC maupun yang beresiko dan demonstrasi tentang cara pencegahan penularan penyakit $\mathrm{TBC}$ tersebut.

Dari analisis situasi tersebut diatas dapat diidentifikasi permasalahan yang dihadapi pada komunitas resiko tinggi tertular TBC adalah sebagai berikut :

1. Kurangnya pengetahuan tentang perilaku sehat khusus untuk penderita TBC dan kelompok resiko untuk mencegah penularan pada orang lain

2. Belum adanya Pembinaan pada kelompok resiko tertular penyakit TBC dari Dinas Kesehatan setempat.

3. Kurang adanya pengetahuan tentang pengadaan dan penyediaan menu TKTP yang efektif dan efisien untuk meningkatkan daya tahan tubuh penderita TBC dan kelompok resiko

4. Perlunya ketrampilan batuk efektif dan postural drainase serta cara pembuangan dahak pada penderita TBC dengan dukungan support sistem keluarga untuk mencegah keparahan dan penularan TBC di keluarga.

Salah Satu upaya tersebut adalah dengan Dinamika Kelompok Sosial dimana dalam kegiatannya akan menghasilkan suatu itikad untuk berbuat sesuatu. Kegiatannya meliputi Promkes tentang perilaku sehat pada penderita TBC, pembuangan dahak penderita, mengajarkan batuk efetif, postural drainage, pembuatan larutan desinfektan dan pemeriksaan BTA untuk mendeteksi angka kejadian TBC, dengan harapan akan terjadi perbaikan dalam pola hidup pasien TBC dan keluarganya yang merupakan resiko tinggi tertular sehingga diharapkan dapat menurunkan angka 
kejadian dan meningkatkan angka penyembuhan.

\section{METODOLOGI PENELITIAN}

Metode penelitian adalah suatu cara dalam melakukan penelitian, metode yang dipilih berhubungan erat dengan prosedur, alat serta desain penelitian yang akan digunakan (Nasir, 1995). Pada bab ini akan dijelaskan metode penelitian yang akan digunakan untuk menjawab tujuan penelitian berdasar masalah yang ditetapkan antara lain desain penelitian, kerangka operasional, desain sampling, pengumpulan dan pengolahan data, etik penelitian dan keterbatasan dalam penelitian.

Desain penelitian merupakan hasil akhir dari suatu tahap keputusan yang dibuat oleh peneliti berhubungan dengan bagaimana penelitian bisa diterapkan (Nursalam, 2003). Dalam penelitian ini, menggunakan desain Pre Eksperimental Design dengan rancangan penelitian One group pre-post test design. Dimana ciri dari desain ini adalah terdapat dua kelompok ekperimental yang diberi perlakuan dan diadakan pengukuran prepost test (Nursalam, 2003).

HASILPENELITIAN

A. Karakteristik Responden

1. Berdasarkan Usia

Tabel 4.1 Distribusi Frekuensi Responden berdasarkan usia

\begin{tabular}{|l|l|l|l|}
\hline No & $\begin{array}{l}\text { Usia } \\
\text { (thn) }\end{array}$ & Frekuensi & Prosentase \\
\hline 1 & $<10$ & 6 & 12 \\
\hline 2 & $11-20$ & 9 & 18 \\
\hline 3 & $21-30$ & 6 & 12 \\
\hline 4 & $31-40$ & 13 & 26 \\
\hline 5 & $41-50$ & 2 & 4 \\
\hline 6 & $51-60$ & 7 & 14 \\
\hline 7 & $61-70$ & 3 & 6 \\
\hline 8 & $71-80$ & 1 & 2 \\
\hline 9 & $81-90$ & 2 & 4 \\
\hline 10 & $>91$ & 1 & 2 \\
\hline & TOTAL & 50 & $100 \%$ \\
\hline
\end{tabular}

Berdasarkan tabel diatas didapatkan bahwa sebagian kecil responden (2\%) berusia 71-80 tahun dan >91 tahun.

\section{Berdasarkan Jenis Kelamin}

Tabel 4.2 Distribusi Frekuensi Responden berdasarkan Jenis Kelamin

\begin{tabular}{|l|l|c|c|}
\hline No & $\begin{array}{l}\text { Jenis } \\
\text { Kelamin }\end{array}$ & Frekuensi & Prosentase \\
\hline 1 & Laki-laki & 23 & $46 \%$ \\
\hline 2 & Perempuan & 27 & $54 \%$ \\
\hline & TOTAL & 50 & $100 \%$ \\
\hline
\end{tabular}

Berdasarkan tabel 4.2 didapatkan

bahwa sebagian responden (54\%) mempunyai jenis kelamin perempuan.

\section{Berdasarkan Penderita TB Dan Kelompok Resiko Tinggi TB Paru}

Tabel 4.3 Distribusi Frekuensi

\begin{tabular}{|c|l|l|l|}
\hline No & Kelompok & Frekuensi & Prosentase \\
\hline 1 & $\begin{array}{l}\text { Penderita } \\
\text { TB }\end{array}$ & 9 & $18 \%$ \\
\hline 2 & $\begin{array}{l}\text { Kelompok } \\
\text { Resti }\end{array}$ & 41 & $82 \%$ \\
\hline & total & 50 & $100 \%$ \\
\hline
\end{tabular}

Responden berdasarkan penderita TB Paru dan Kelompok Resiko Tinggi TB Paru

Berdasarkan tabel di atas didapatkan bahwa sebagian besar merupakan kelompok resiko tinggi TB Paru (82\%) dan sebanyak 18\% adalah penderita TB Paru.

\section{Berdasarkan Ada Tidaknya Gejala yang Muncul}

Tabel 4.4 Distribusi Frekuensi Responden berdasarkan Ada Tidaknya Gejala yang Muncul

\begin{tabular}{|l|l|l|l|}
\hline No & Gejala & Frekuensi & Prosentase \\
\hline 1 & Ada & 6 & $12 \%$ \\
\hline 2 & $\begin{array}{l}\text { Tidak } \\
\text { ada }\end{array}$ & 44 & $88 \%$ \\
\hline & total & 50 & $100 \%$ \\
\hline
\end{tabular}

Berdasarkan tabel 4.4 didapatkan bahwa sebagian besar responden $(88 \%)$ tidak muncul gejala. Semua responden 
yang muncul gejala klinis merupakan pasien yang menjalani pengobatan OAT.

\section{Berdasarkan Gejala yang muncul}

Tabel 4.4 Distribusi Frekuensi Responden berdasarkan Gejala yang Muncul

\begin{tabular}{|l|l|l|l|}
\hline No & $\begin{array}{l}\text { Gejala } \\
\text { yang } \\
\text { muncul }\end{array}$ & Frekuensi & Prosentase \\
\hline 1 & Flu & 1 & $17 \%$ \\
\hline 2 & Batuk & 5 & $83 \%$ \\
\hline & Total & 6 & $100 \%$ \\
\hline
\end{tabular}

Berdasarkan tabel diatas didapatkan bahwa sebagaian besar responden $(83 \%)$ muncul gejala batuk.

\section{B. Hasil Pemeriksaan Sputum (pagi) Sebelum Dilakukan Dinamika Kelompok}

Tabel 4.5 Distribusi Frekuensi Pemeriksaan Sputum (Pagi) Sebelum Dilakukan Dinamika Kelompok

\begin{tabular}{|l|l|l|l|}
\hline No & $\begin{array}{l}\text { Hasil } \\
\text { Pemeriksaan } \\
\text { Sputum }\end{array}$ & Frekuensi & Prosentase \\
\hline 1 & Positif & 1 & $2 \%$ \\
\hline 2 & Negatif & 49 & $98 \%$ \\
\hline & Total & 50 & 100 \\
\hline
\end{tabular}

Dari tabel 4.5 dapat diketahui bahwa hasil pemeriksaan sputum (pagi) sebelum dilakukan dinamika kelompok untuk hampir seluruh responden (98\%) adalah negatif.

\section{Hasil Pemeriksaan Sputum (Sewaktu) Sebelum Dilakukan Dinamika Kelompok}

Tabel 4.6 Distribusi Frekuensi Pemeriksaan Sputum (sewaktu) Sebelum Dilakukan Dinamika Kelompok

\begin{tabular}{|l|l|l|l|}
\hline No & $\begin{array}{l}\text { Hasil } \\
\text { Pemeriksaan } \\
\text { Sputum }\end{array}$ & Frekuensi & Prosentase \\
\hline 1 & Positif & 1 & $2 \%$ \\
\hline 2 & Negatif & 49 & $98 \%$ \\
\hline & Total & 50 & 100 \\
\hline
\end{tabular}

Dari tabel diatas dapat diketahui bahwa hasil pemeriksaan sputum (sewaktu) sebelum dilakukan dinamika kelompok untuk hampir seluruh responden (98\%) adalah negatif.

\section{Hasil Pemeriksaan Sputum (pagi) Setelah Dilakukan Dinamika Kelompok}

Tabel 4.7 Distribusi Frekuensi Pemeriksaan Sputum (pagi) Setelah Dilakukan Dinamika Kelompok

\begin{tabular}{|l|l|l|l|}
\hline No & $\begin{array}{l}\text { Hasil } \\
\text { Pemeriksaan } \\
\text { Sputum }\end{array}$ & Frekuensi & Prosentase \\
\hline 1 & Positif & 0 & $0 \%$ \\
\hline 2 & Negatif & 50 & $100 \%$ \\
\hline & Total & 50 & 100 \\
\hline
\end{tabular}

Dari tabel diatas dapat diketahui bahwa hasil pemeriksaan sputum (pagi) setelah dilakukan dinamika kelompok untuk seluruh responden $(100 \%)$ adalah negatif.

\section{E. Hasil Pemeriksaan Sputum (Sewaktu) Setelah Dilakukan Dinamika Kelompok}

Tabel 4.8 Distribusi Frekuensi Pemeriksaan Sputum (sewaktu) setelah dilakukan Dinamika Kelompok

\begin{tabular}{|l|l|l|l|}
\hline No & $\begin{array}{l}\text { Hasil } \\
\text { Pemeriksaan } \\
\text { Sputum }\end{array}$ & Frekuensi & Prosentase \\
\hline 1 & Positif & 0 & $0 \%$ \\
\hline 2 & Negatif & 50 & $100 \%$ \\
\hline & Total & 50 & 100 \\
\hline
\end{tabular}

Dari tabel 4.8 dapat diketahui bahwa hasil pemeriksaan sputum (sewaktu) setelah dilakukan dinamika kelompok untuk seluruh responden (100\%) adalah negatif. 


\section{F. Pengaruh Dinamika Kelompok terhadap Angka Kejadian Tuberkulosis dan Penyembuhan Penyakit Tuberkulosis Paru}

Tabel 4.9 Pengaruh Dinamika Kelompok terhadap Angka Kejadian Tuberkulosis dan Penyembuhan Penyakit Tuberkulosis Paru di wilayah kerja Puskesmas Sukorame Kota Kediri

\begin{tabular}{|l|l|l|l|}
\hline \multicolumn{2}{|l|}{ Sebelum dinamika } & \multicolumn{2}{l|}{ Setelah dinamika } \\
\hline \multicolumn{2}{|l|}{ Hasil BTA } & \multicolumn{2}{l|}{ Hasil BTA } \\
\hline $\begin{array}{l}\text { Positif } \\
(+)\end{array}$ & 1 & Positif (+) & 0 \\
\hline $\begin{array}{l}\text { Negatif } \\
(-)\end{array}$ & 49 & Negatif (-) & 50 \\
\hline
\end{tabular}

\begin{tabular}{|l|l|l|}
\hline \multirow{2}{*}{ Sebelum } & \multicolumn{2}{|l|}{ Sesudah } \\
\cline { 2 - 3 } & Positif (+) & Negatif (-) \\
\hline Positif(+) & 0 & 1 \\
\hline Negatif (-) & 0 & 49 \\
\hline Jumlah & 0 & 50 \\
\hline
\end{tabular}

$$
\begin{gathered}
\mathrm{X}^{2=}([\mathrm{A}-\mathrm{D}]-1)^{2}=\left(\frac{[0-1]-1)^{2}}{1}\right. \\
\mathrm{X}^{2}=9
\end{gathered}
$$

Jadi harga $X^{2}$ hitung $=9$

Bila $\mathrm{dk}=$, taraf kesalahan $5 \%$, chi kuadrat tabel $=3,481$. Bila chi kuadrat $\leq$ chi kuadrat tabel Ho diterima Ha ditolak. Perhitungan chi kuadrat hitung lebih besar dari tabel (9> 3,481). Kesimpulan, Ho ditolak, Ha diterima.

\section{PEMBAHASAN}

\section{A. Angka Kejadian TBC Paru}

Pada pelaksanaan pemeriksaan dahak pagi hari sebelum dilakukan dinamika kelompok pada responden menunjukkan bahwa hampir seluruh responden (98\%) didapatkan hasil negatif, begitu juga pada pemeriksaan dahak sewaktu ( pemeriksaan dahak 2 jam setelah dahak pagi hari) hasil yang didapatkan $\quad 98 \%$ (hampir seluruh responden) negatif. Setelah dilakukan dinamika kelompok didapatkan hasil pemeriksaan dahak pagi seluruh responden (100\%) didapatkan hasil negatif, begitu juga pada pemeriksaan dahak sewaktu hasil yang didapatkan 100\% (seluruh responden) negatif.

Diagnosis TBC Paru (Tuberculosis) pada orang dewasa dapat ditegakkan dengan ditemukannya BTA (Bakteri Tahan Asam) pada pemeriksaan dahak secara mikroskopis hasil pemeriksaan dinyatakan positif apabila sedikitnya dua dari tiga spesimen hasilnya positif. Bila hanya 1 spesimen yang positif perlu diadakan pemeriksaan lebih lanjut yaitu foto rontgen dada atau pemeriksaan dahak diulang. Kalau hasil rontgen mendukung TBC, maka penderita didiagnosis sebagai penderita TBC positif. Sedangkan jika hasil rontgen tidak mendukung TBC, maka pemeriksaan dahak diulangi. Sedangkan, diagnosa TB Paru BTA negatif, bilamana pemeriksaan 3 spesimen dahak SPS (Sewaktu Pagi dan Sewaktu) hasilnya BTA negatif dan foto rontgen dada menunjukkan gambar tuberkulosis tidak aktif.

Beberapa faktor yang mempengaruhi hasil pemeriksaan dahak, antara lain:

1) Pengambilan bagian dahak yang representatif. Dari data di dapatkan hanya $12 \%$ dari responden yang terdapat gejala (flu dan batuk), sedangkan pengambilan dahak pada anak dan orang dewasa yang tanpa keluhan batuk lama sulit dan jarang didapatkan diagnosis TBC.

2) Waktu perawatan yang tepat

Jika dalam 2 bulan, penderita menggunakan OAT terdapat perbaikan klinis akan menunjang atau memperkuat diagnosis TBC. Dari data di dapatkan semua pasien (12\% dari responden) yang menjalani pengobatan OAT masih terdapat gejala (flu dan batuk). Sedangkan, anggota keluarga sebanyak $88 \%$ tidak didapatkan gejala klinis. Untuk itu penting memikirkan adanya suspect TBC jika terdapat gejala yang mencurigakan seperti dibawah ini :

a) Mempunyai sejarah kontak erat (serumah) dengan penderita TBC BTA positif, b) Berat badan turun selama 3 
bulan berturut-turut dan tidak naik dalam 1 bulan meskipun sudah dengan penanganan gizi yang baik (failure to thrive), c) Nafsu makan tidak ada (anoreksia) dengan gagal tumbuh dan berat badan tidak naik dengan adekuat, d) Demam lama/berulang tanpa sebab yang jelas disertai keringat malam, e) Pembesaran kelenjar limfe superfisialis yang tidak sakit biasanya multiple (pembesaran kelenjar limfe di berbagai tempat) paling sering didaerah leher ketiak dan lipatan paha (inguinal), f) gejala dari saluran nafas misalnya batuk lama lebih dari 30 hari dan nyeri dada.

Pemantauan kemajuan hasil pengobatan pada orang dewasa dilaksanakan dengan pemeriksaan ulang dahak secara mikroskopis. Pemeriksaan dahak secara mikroskopis lebih baik dibandingkan dengan pemeriksaan radiologis dalam memantau kemajuan pengobatan. Untuk memantau kemajuan pengobatan dilakukan pemeriksaan spesimen sebanyak dua kali (sewaktu dan pagi). Hasil pemeriksaan dinyatakan negatif bila ke 2 spesimen tersebut negative, bila salah satu spesimen positif, maka hasil pemeriksaan ulang dahak tersebut dinyatakan positif. Pemeriksaan ulang dahak untuk memantau kemajuan pengobatan dilakukan pada :

\section{a) Akhir tahap Intensif}

Dilakukan seminggu sebelum akhir bulan ke 2 pengobatan penderita baru BTA positif dengan kategori 1,atau seminggu sebelum akhir bulan ke 3 pengobatan ulang penderita BTA positif dengan kategori 2. Pemeriksaan dahak pada akhir tahap intensif dilakukan untuk mengetahui apakah telah terjadi konversi dahak yaitu perubahan dari BTA positif menjadi negatif.

A. Pengobatan penderita baru BTA positif dengan kategori 1 :

Akhir bulan ke 2 pengobatan sebagian besar (seharusnya $>80 \%$ ) dari penderita dahak nya sudah BTA negatif (konversi). Penderita ini dapat meneruskan pengobatan dengan tahap lanjutan. jika pemeriksaan ulang dahak pada akhir bulan ke 2 hasilnya masih BTA positif, pengobatan diteruskan dengan OAT (Obat Anti Tuberculosis) sisipan selama 1 bulan. Setelah paket sisipan satu bulan selesai, dahak diperiksa kembali, Pengobatan tahap lanjutan tetap diberikan meskipun hasil pemeriksaan ulang dahak BTA masih tetap positif.

B. Pengobatan ulang penderita BTA positif dengan kategori 2:

Jika pemeriksaan ulang dahak pada akhir bulan ke 3 masih positif, tahap intensif harus diteruskan lagi selama 1 bulan dengan OAT sisipan, Setelah satu bulan diberi sisipan dahak diperiksa kembali. Pengobatan tahap lanjutan tetap diberikan meskipun hasil pemeriksaan dahak ulang BTA masih positif. Bila hasil uji kepekaan obat menunjukan bahwa kuman sudah resisten tehadap 2 atau lebih jenis OAT,maka penderita tersebut dirujuk ke unit pelayanan spesialistik yang dapat menangani kasus resisten. Bila tidak mungkin, maka pengobatan dengan tahap lanjutan diteruskan sampai selesai.

C. Pengobatan penderita BTA negatif rontgen positif dengan kategori 3 (ringan) atau kategori 1 (berat) :

Penderita TBC paru BTA negatif, rontgen positif, baik dengan pengobatan kategori 3 (ringan) atau kategori 1 (berat) tetap dilakukan pemeriksaan ulang dahak pada akhir bulan ke 2. Bila hasil pemeriksaan ulang dahak BTA positif maka ada 2 kemungkinan:

1. Suatu kekeliruan pada pemeriksaan pertama (pada saat diagnosis sebenarnya adalah BTA positif tapi dilaporkan sebagai BTA negatif).

\section{Penderita berobat tidak teratur}

Seorang penderita yang diagnosa sebagai penderita BTA negatif dan diobati dengan kategori 3 yang hasil pemeriksaan ulang dahak pada akhir bulan ke 2 adalah BTA positif harus didaftar kembali sebagai penderita gagal BTA positif dan mendapat pengobatan dengan kategori 2 mulai dari awal. Bila pemeriksaan ulang 
dahak akhir tahap intensif pada penderita baru dan penderita pengobatan ulang BTA positif, dahak menjadi BTA negatif pengobatan diteruskan ketahap lamjutan. Bila pada pemeriksaan ulang dahak akhir pada tahap akhir intensif penderita BTA negatif Rontgen positif dahak menjadi BTA positif, penderita dianggap gagal dan dimulai pengobatan dari permulaan dengan kategori 2.

\section{b) Sebulan sebelum akhir pengobatan}

Dilakukan seminggu sebelum akhir bulan ke 5 pengobatan penderita baru BTA positif dengan kategori 1, atau seminggu sebelum akhir bulan ke 7 pengobatan ulang menderita BTA positif dengan katagori 2

\section{c) Akhir pengobatan}

Dilakukan seminggu sebelum akhir bulan ke 6 pengobatan pada penderita baru BTA positif dengan kategori 1, atau seminggu sebelum akhir bulan ke 8 pengobatan ulang BTA positif, dengan kategori 2. Pemeriksaan ulang dahak pada sebulan sebelum akhir pengobatan dan akhir pengobatan (AP) bertujuan untuk menilai hasil pengobatan ( sembuh atau gagal). Penderita dinyatakan sembuh bila penderita telah menyelesaikan pengobatan secara lengkap dan pemeriksaan ulang dahak (follow up paling sedikit 2 kali berturut-turut hasilnya negative (pada AP dan / atau sebulan Ap, dan pada satu pemeriksaan follow up sebelumnya).

\section{B. Pengaruh Dinamika Kelompok terhadap Angka Kejadian Tuberkulosis dan Penyembuhan Penyakit Tuberkulosis Paru}

Berdasarkan analisis data dengan menggunakan McNemar-Bowker Test menunjukkan tidak ada pengaruh yang signifikan dinamika kelompok terhadap angka kejadian tuberkulosis dan penyembuhan penyakit tuberkulosis paru. Pemeriksaan sputum adalah terlaksana tidaknya pemeriksaan mikroskopis dahak tersangka atau penderita TB paru pada saat pertama kali penderita datang dan pada saat dua bulan setelah pengobatan, pada akhir sisipan kalau ada sisipan, dan pada bulan kelima serta keenam pada akhir pengobatan. Di samping itu, pemeriksaan sputum juga dapat memberikan evaluasi terhadap pengobatan yang sudah diberikan. Sebagian besar hasil pemeriksaan sputum sebelum dan sesudah dinamika kelompok dilakukan negatif, disebabkan beberapa faktor: 1) kesulitan untuk mengeluarkan dahak ketika pasien tidak batuk produktif atau pemeriksaan dahak yang berulang-ulang, 2) Pengobatan penderita baru BTA positif dengan kategori 1. Akhir bulan ke 2 pengobatan sebagian dari penderita,dahak nya sudah BTA negatif (konversi). Penderita ini dapat meneruskan pengobatan dengan tahap lanjutan. jika pemeriksaan ulang dahak pada akhir bulan ke 2 hasilnya masih BTA positif, pengobatan diteruskan dengan OAT sisipan selama 1 bulan. Setelah paket sisipan satu bulan selesai, dahak diperiksa kembali, Pengobatan tahap lanjutan tetap diberikan meskipun hasil pemeriksaan ulang dahak BTA masih tetap positif.

Pemeriksaan sputum penting karena dengan ditemukannya kuman BTA, diagnosis tuberkulosis sudah dapat dipastikan. Di samping itu pemeriksaan sputum juga dapat memberikan evaluasi terhadap pengobatan yang sudah diberikan. Tetapi, tidak mudah untuk mendapat sputum, terutama pasien yang tidak batuk atau batuk yang non produktif. Dalam hal ini dianjurkan satu hari sebelum pemeriksaan sputum, pasien dianjurkan minum air sebanyak +2 liter dan diajarkan melakukan refleks batuk. Dapat juga dengan memberikan tambahan obat-obat mukolitik eks-pektoran atau dengan inhalasi larutan garam hipertonik selama 20-30 menit. Bila masih sulit, sputum dapat diperoleh dengan cara bronkoskopi diambil dengan brushing atau bronchial washing atau BAL (Broncho Alveolar Lavage). BTA dari sputum bisa juga didapat dengan cara bilasan lambung. Hal ini sering dikerjakan pada 
anak-anak karena mereka sulit mengeluarkan dahaknya. Sputum yang akan diperiksa hendaknya sesegara mungkin. Bila sputum sudah didapat. kuman BTA pun kadang sulit ditemukan. Kuman BTA dapat ditemukan bila bronkus yang terlibat proses penyakit ini terbuka ke luar, sehingga sputum yang mengandung kuman BTA mudah ke luar. Tidak semua pasien memberikan sediaan atau biakan sputum yang positif karena kelainan paru yang belum berhubungan dengan bronkus atau pasien tidak bisa membatukkan sputumnya dengan baik. Kelainan baru jelas setelah penyakit berlanjut sekali.

\section{Daftar Pustaka}

Arikunto, S. (2002). Manajemen Penelitian. edisi kelima. Jakarta: Rineka Cipta, Hal : 178-198.
Arikunto, S. (2006). Prosedur Penelitian: Suatu Pendekatan Praktik. Edisi 6. Jakarta: Rineka Cipta.

Alimul, A.(2003). Riset Keperawatan dan Teknik Penulisan Ilmiah. Jakarta: Salemba Medika.

Azwar, A. (2003). Sikap Manusia: Teori Dan Pengukurannya. Yogyakarta: Pustaka Pelajar, Hal 4-5, 15-17, 23-24, 30-38.

Notoatmodjo, S. (2003). Pendidikan Dan Perilaku Kesehatan edisi pertama. Jakarta: Rineka Cipta, hal 12-15.

Nursalam, (2003). Konsep Dan Penerapan Metodologi Penelitian Ilmu Keperawatan: Pedoman Skripsi, Tesis, Dan Instrumen Penelitian Keperawatan. Jakarta: Salemba Medika, hal 80-220. 